\title{
Eunotia enigmatica sp. nov., a new planktonic diatom from Brazil and the transfer of Fragilaria braunii Hustedt to the genus Peronia (Bacillariophy- ceae)
}

\author{
Lívia F. Costa ${ }^{1,2 *}$, Carlos E. Wetzel ${ }^{2}$, Luc Ector ${ }^{2}$, David M. Williams ${ }^{3} \&$ Denise \\ C. BICUDO ${ }^{1}$
}

\author{
${ }^{1}$ Instituto de Botânica, Ecology Department, São Paulo, Brazil; *Corresponding author e-mail: livia.fcosta@, \\ hotmail.com \\ ${ }^{2}$ Luxembourg Institute of Science and Technology (LIST), Environmental Research and Innovation Department \\ (ERIN), Belvaux, Luxembourg \\ ${ }^{3}$ Natural History Museum, Life Sciences Department, Cromwell Road, London, UK
}

\begin{abstract}
Eunotia is a diatom genus characterized by a short raphe system restricted to both valve poles and by the presence of rimoportulae. As part of a survey examining the genus, Eunotia enigmatica sp. nov. is described from ultra oligo- to oligotrophic and slightly acidic reservoirs in São Paulo State, southeast Brazil. The species is unusual in having a short distinct raphe, and a 'fragilarioid' appearance with long cells and marginal spines. It was commonly found in the planktonic community as well as on sediments of the studied reservoirs. It seems to be adapted to an open water existence, and is similar to E. croatana and E. pseudofragilaria both described from North America. Additionally, type material of another similar looking species, Fragilaria braunii, was analysed using light and scanning electron microscopy and a new combination is proposed for it in the genus Peronia.
\end{abstract}

Key words: Eunotia, Fragilaria, Peronia, reservoirs, rimoportulae, scanning electron microscopy, sediments, short raphe, taxonomy, type material

\section{INTRODUCTION}

The order Eunotiales P.C. SILVA includes two diatom families: Peroniaceae (Karsten) Topachevs'Ky et OKSIYUK and Eunotiaceae KützIng. Only Peronia BréBISson et ArnotT ex Kitton and Actinellopsis J.C. TAYLor, B. Karthick et KocIolek have been placed in Peroniaceae, whereas Eunotiaceae has a greater number of genera: Eunotia Ehrenberg, Actinella F.W. Lewis, Amphorotia D.M. Williams et G. Reid, Bicudoa C.E. Wetzel, Lange-Bertalot et Ector, Colliculoamphora D.M. Williams et G. Reid, Desmogonium Ehrenberg in Schomburgk, Eunotioforma Kociolek et Burliga, Eunophora Vyverman, Sabbe et D.G. Mann in Vyverman et al., Perinotia Metzeltin et Lange-BertaLot, and Semiorbis R.M. Patrick in Patrick \& Reimer (Round et al. 1990).

Diversity in Peroniaceae is low, currently including only six valid species: four in Peronia, $P$. erinacea BréBISSON ex KütZING, P. fibula (BréBISSON ex Kützing) R. Ross, $P$. brasiliensis Hustedt and $P$. heribaudii BRUN \& HéRIBAUD, and two in Actinellopsis
(TAYLOR et al. 2014). Traditionally, Peronia has heteropolar frustules, and appears cuneate in both valve and girdle view (Spaulding 2015). The frustules are also heterovalvar: the raphe system is well developed on one valve with a rimoportula at each valve apex; the other valve possesses one rimoportula and a very short raphe, or the raphe is completely absent on this valve altogether (Round et al. 1990). In addition, the family Peroniaceae differs from Eunotiaceae mainly due to the position of the raphe system on the valve face as in naviculoid diatoms, rather than on the mantle (WILLIAMS \& ReID 2008; KocioleK et al. 2015).

Eunotia is the largest genus in the family Eunotiaceae with at least 1500 species distributed globally (Round et al. 1990; Lange-Bertalot et al. 2011). In recent years, many new taxa have been described and revisions have mainly focused on the diversity of the genus which has clearly been underestimated (WeTZEL et al. 2010, 2011; Furey et al. 2011; Lange-Bertalot et al. 2011; Burliga et al. 2013; Pavlov \& Levkov 2013; Potapova et al. 2014; Van de ViJver et al. 2014; KulikovskiY et al. 2015). 
Eunotia is characterized by a short raphe system restricted to both valve poles with an internally well-developed helictoglossa and the presence of rimoportulae (Round et al. 1990; SIVER et al. 2006). It is classically known by species that are symmetric about the transapical and planar axes in both valve and girdle view but asymmetric about the apical axis due to the lunate shape of the frustule and position of the raphe (PATRICK \& REIMER 1966).

Among the raphe-bearing diatoms, the order Eunotiales is the only group with one or more rimoportulae (KocioleK et al. 2015). Eunotiaceae has often been considered an intermediate group of diatoms situated somewhere between the 'araphid' and raphid diatoms (SimONSEN 1979). It is now reasonably well supported by molecular studies that the family is monophyletic and is sister taxon to all other raphid pennate diatoms (e.g. THERIOT et al. 2010). The relationships amongst its various members, however, are anything but settled (Williams \& Reid 2006; Burliga et al. 2013). This certainly has consequences for the genera currently recognized, especially since there are still many species in need of description.

Most species of Eunotia are found in freshwater environments, although examples of marine fossil species similar to modern freshwater taxa exist (e.g. NoVITSKI \& KocIOleK 2005). The genus Eunotia is usually more diversified in dystrophic or acidic waters, and its species are predominantly found in the benthos, rarely occurring in the phytoplankton as well (KOCIOLEK 2000; Siver et al. 2006). However, some species are known to be truly planktonic, such as Eunotia asterionelloides Hustedt, E. croatana Siver, P.B. Hamilton et E. MoRales, E. gomesii C.E. Wetzel et Ector in Wetzel et al., E. loboi C.E. Wetzel et Ector in Wetzel et al., E. pseudofragilaria Siver, P.B. Hamilton et E. Morales, E. tukanorum C.E. Wetzel et D. Bicudo in Wetzel et al., E. waimiriorum C.E. Wetzel in Wetzel et al. and E. zasuminensis (CABEJSZEKównA) KöRner (CABEJSZEKówna 1937; Hustedt 1952; Siver et al. 2006; Wetzel et al. 2010), and are dominant in oligotrophic rivers and reservoirs in Brazil (ALMEIDA \& BiCUDO 2014; FoNTANA et al. 2014).

As part of a survey examining the genus Eunotia in São Paulo State reservoirs, planktonic populations of a new species with a particular combination of features were observed. Hence, one of the objectives of this study is to formally describe this new species. Additionally, the type material of Fragilaria braunii HuSTEDT, a very similarly looking species described from the Brazilian Amazon, was studied using light (LM) and scanning electron microscopic (SEM) techniques. As a result, a new combination for this species is proposed, as short raphe slits were discovered on the valve face.

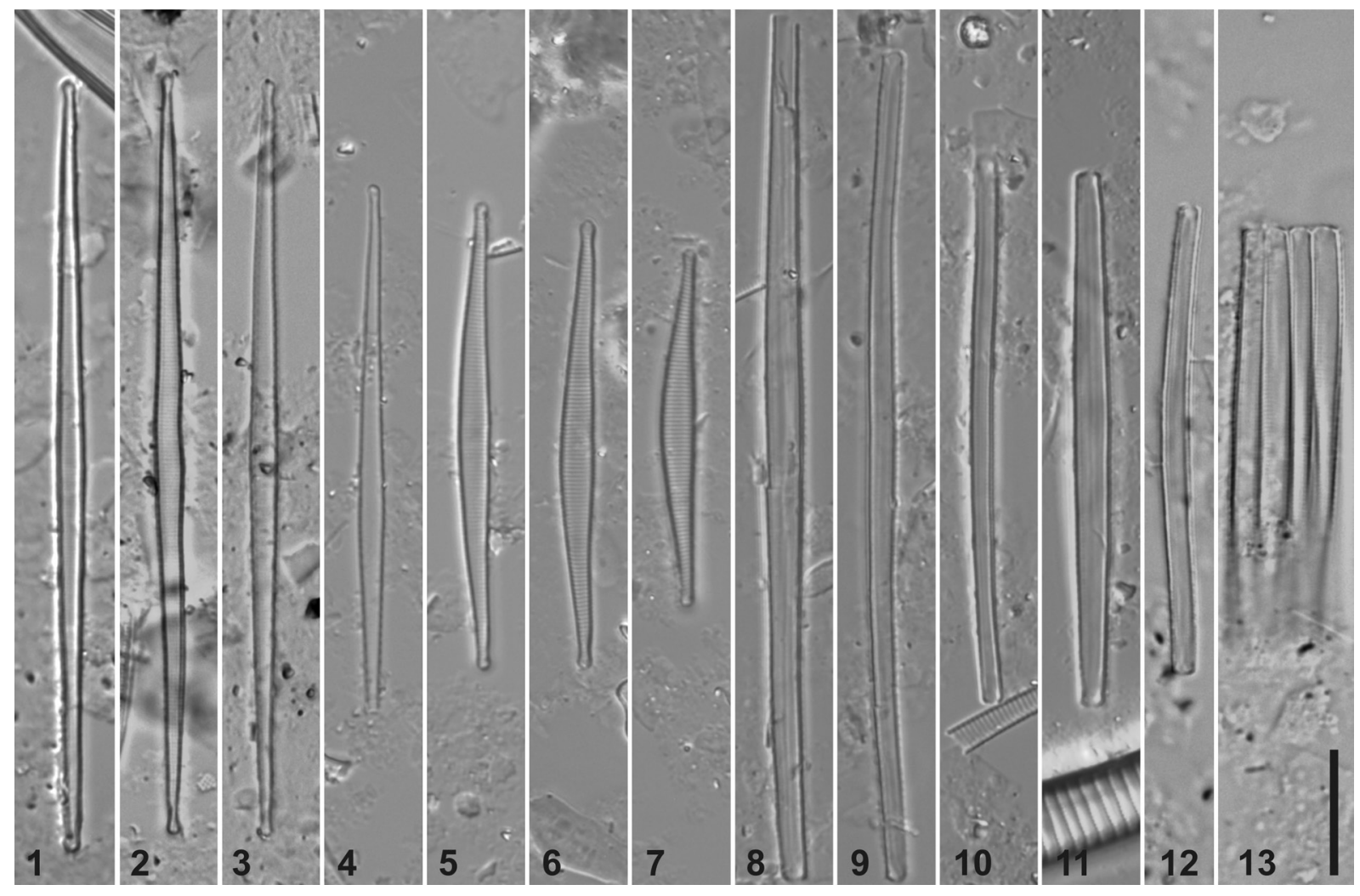

Figs 1-13. Eunotia enigmatica sp. nov. from Pedro Beicht reservoir, LM images: (1-7) Specimens in valve view; (8-13) Specimens in girdle view; (13) Colony of four cells. Scale bar $10 \mu \mathrm{m}$. 


\section{Materials ANd Methods}

Study Area. Pedro Beicht and Ribeirão do Campo reservoirs are located in conservation areas of the Atlantic Forest remnants in the Alto Tietê River Basin, State of São Paulo, Southeastern Brazil. Climate conditions are tropical, that is, dry with mild temperatures in winter and rainy with warm temperatures in summer (CEPAGRI 2015). Pedro Beicht Reservoir (PBR) is located in the Reserva Florestal Morro Grande between the coordinates $23^{\circ} 39^{\prime}-23^{\circ} 44^{\prime} \mathrm{S}$ and $46^{\circ} 57^{\prime}-$ $46^{\circ} 58^{\prime} \mathrm{W}$. It was built in 1933 , has a surface area of $2.9 \mathrm{~km}^{2}$ and maximum depth of $10 \mathrm{~m}$. Ribeirão do Campo Reservoir (RCR) is situated between the coordinates $23^{\circ} 38^{\prime}-23^{\circ} 39^{\prime} \mathrm{S}$ and $45^{\circ} 49^{\prime}-45^{\circ} 50^{\prime} \mathrm{W}$, was built in 1958 , has a surface area of $1.6 \mathrm{~km}^{2}$ and maximum depth of $14 \mathrm{~m}$. Limnological characteristics for PBR are available in AlmEIDA \& BICUdo (2014) and for RCR in the AcquaSed database Project (see Bicudo et al. 2016). Both reservoirs present good ecological status with acidic to slightly acidic waters, low conductivity and low nutrient availability. PBR is oligotrophic ( $\mathrm{pH} 5.4-6.6$, conductivity $13-19 \mu \mathrm{S} . \mathrm{cm}^{-1}$, total phosphorus $9.8-16.5 \mu \mathrm{g} . l^{-1}$, total nitrogen 125-332 $\left.\mu \mathrm{g} .1^{-1}\right)$, and RCR is ultra-oligotrophic with

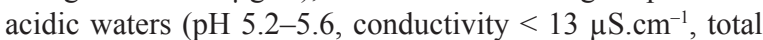
phosphorus $<5.2 \mu \mathrm{g} .1^{-1}$, total nitrogen $230-565 \mu \mathrm{g} .1^{-1}$ ). The ranges for trophic state classification followed the proposal for tropical/subtropical reservoirs (CUNHA et al. 2013).

Sampling and sample treatment. Sampling was carried out in three sites at PBR and two sites at RCR during the summer and winter of 2010. Phytoplankton was collected with a Van Dorn sampler from the surface, middle and bottom of the water column and with a plankton net $(20 \mu \mathrm{m}$ mesh) from the surface. Benthos was scraped from rocks and macrophytes, and surface sediment samples were collected using a gravity core, saving the top $2 \mathrm{~cm}$ sections for analyses. In total, 18 samples were examined: 11 from PBR (six planktonic, two benthic, and three of surface sediment) and seven from RCR (three planktonic, two benthic, and two of surface sediment). Diatom samples were digested with concentrated $35 \% \mathrm{H}_{2} \mathrm{O}_{2}$ and $37 \% \mathrm{HCl}$, according to the European CommitTeE FOR STANDARDIZATION (2014). Cleaned material was diluted with deionized water, dried onto coverslips and mounted on slides using Naphrax ${ }^{\circledR}$ mounting medium. Optical microscopy analysis was performed using a light microscope, Zeiss Axio Imager A2, equipped with Differential Interference Contrast (DIC) optics and a high-resolution digital camera (MRC5). For scanning electron microscopy, small aliquots of oxidized samples were filtered through a polycarbonate membrane filter $(3 \mu \mathrm{m})$, and washed with deionized water. Filters were mounted on aluminium stubs and coated with platinum. Micrographs were taken with a Hitachi SU-70 operated at $5 \mathrm{kV}$ and $10 \mathrm{~mm}$ working distance. Photomicrographs were digitally manipulated and figure plates containing light and scanning electron microscopy images were created using CorelDraw X6. The holotype slide was deposited in the Herbário Científico do Estado Maria Eneyda P. Kauffmann Fidalgo, Instituto de Botânica, São Paulo, Brazil (SP), and the isotype slide was deposited in the Botanic Garden Meise, Belgium (BR). The sample of Fragilaria braunii type material from the Hustedt Collection (BRM, Friedrich Hustedt Diatom Study Center, Alfred-Wegener-Institut Helmholtz-Zentrum für Polar- and Meeresforschung, Bremerhaven, Germany), BRM material number AM1018, was also analysed using LM and SEM using a new set of slides and stubs.

\section{ReSUlts}

Eunotia enigmatica L.F. Costa et C.E. Wetzel sp. nov. (Figs 1-29)

Light microscopy: Frustules usually solitary (Figs 1-12), rarely forming ribbon-like colonies (Fig. 13), rather irregular in girdle view (i.e. sinuous to narrow rectangular) (Figs 8-12). Valves narrow linear, needleshaped, with sub-capitate apices (Figs 1-7). Smaller specimens with slight dorsiventrality (Figs $5-7$ ), not clearly defined in longer specimens (Figs 1-4) with linear and needle-shaped valves. Terminal raphe nodules very small, almost inconspicuous at each apex (Fig. 5). Valves $26.7-61.1 \mu \mathrm{m}$ long, and 1.8-3.0 $\mu \mathrm{m}$ wide at middle. Striae parallel and equidistant (Fig. 7), 30-34 in $10 \mu \mathrm{m}$. Areolae inconspicuous. Girdle view sinuous to narrow rectangular (Figs 8-12).

Scanning electron microscopy: External valve face striation undulating, i.e. with small siliceous ridges (virgae sensu Cox \& Ross 1981) in between the punctae (Fig. 16). Marginal striation with a narrowly lanceolate sternum (Figs 14, 16). Valve mantle perpendicular to valve face, with striae interrupted by marginal spines along valve face-mantle junction (Fig. 18). Spines solid at both dorsal and ventral sides, formed by fusion of two or three virgae at mantle border (Figs 15-17, 23-25), some with a double row of areolae (Figs 18, 24). Striae uniseriate, areolae openings simple, rounded, occluded by a silica layer (Figs 16, 25); 65-70 in 10 $\mu \mathrm{m}$. Raphe-sternum narrow with filiform short raphe on ventral valve mantle with distal raphe endings on valve face (Figs 15, 17). Internal valve face with small helictoglossa at each apex (Figs 26, 27). Single small rimoportula per valve at one apex (Fig. 28). Frustules in girdle view sinuous with three open bands (Figs 18, 19).

Etymology: The specific epithet was given due the enigmatic features of the species, considering the valve outline is similar to many species in some freshwater 'araphid' diatoms (e.g. Fragilaria) and the presence of the raphe system typical of Eunotia.

Holotype (designated here): Slide SP427581, deposited at the Herbário Científico do Estado Maria Eneyda P. Kauffmann Fidalgo, Instituto de Botânica, São Paulo, Brazil.

Iconotype: Fig. 5.

Isotype: Slide BR-4443, Botanic Garden Meise, Belgium.

Type locality: Brazil, São Paulo, Cotia, Pedro Beicht Reservoir, 46 $58^{\prime} 5.10^{\prime \prime} \mathrm{W}, 23^{\circ} 43^{\prime} 44.06^{\prime \prime S}$. Collected from the surface sediment by P.D. Almeida and D. Bicudo on 18 June 2010.

Remark: Eunotia enigmatica differs from other Eunotia species by a unique combination of features that in- 
cludes the needle-shaped valve outline with sub-capitate apices. It differs from Eunotia pseudofragilaria by having conspicuous marginal spines and a higher striae density.

Ecology and distribution: Eunotia enigmatica occurred in high abundance (maximum of $4.2 \%$ ) in phytoplankton but was also observed in less numbers in the benthic assemblages and surface sediments. It was found in ultra-oligotrophic waters (total phosphorus $<$ $15.4 \mu \mathrm{g} . \mathrm{l}^{-1}$ and total nitrogen $<400 \mu \mathrm{g} . \mathrm{l}^{-1}$ ) with low $\mathrm{pH}$ (5.4-6.4) and very low conductivity $\left(<15 \mu \mathrm{S} . \mathrm{cm}^{-1}\right)$.

\section{Peronia braunii (Hustedt) L.F. Costa, C.E. Wetzel} et D.M. Williams comb. nov. (Figs 30-56)

Basionym: Fragilaria braunii HustedT 1952, Botaniska Notiser 4: p. 379 , figs $41-42$.

Light microscopy: Valves linear-lanceolate in valve view, needle-shaped with acute apices (Figs 30-34), 59-90 $\mu \mathrm{m}$ long, 2-3.2 $\mu \mathrm{m}$ wide at the middle. Striae parallel and equidistant, almost inconspicuous (Fig. 31), 31 in $10 \mu \mathrm{m}$. Areolae inconspicuous, marginal spines present (Fig. 31)

Scanning electron microscopy: External valve face smooth (Fig. 41). Marginal spines solid (Figs 40, 3637), extended outwards from virgae (Fig. 53), tilted towards poles, significantly more developed at apices (Figs 36-37, 55-56). Spines flat (Fig. 39), either bifurcated (Figs 40, 47) or pointed (Figs 36-38). Striation discontinuous by the straight axial area (sternum), uniseriate (Figs 41, 49). Areolae openings extremely small, simple and rounded (Fig. 41), 45-50 in $10 \mu \mathrm{m}$. Vestigial raphe internally (Figs 45-46) and externally (Figs 43-44) in central area of each apex. Single welldeveloped rimoportula present at each apex, situated at base of large apical spine (Figs 43, 45-46). Frustules in girdle view narrow, without striation or with 1-2 rows of pores on mantle, with four or five open bands (Figs 35-37, 52-56). Valvocopula 3-4 times wider than other copulae; each copula overlapping with the previous band, but not extending to the pole (Figs 36, 37).

Holotype: Slide BRM 318/2 (three specimens under finder coordinates: 494.2-5; 557.7; 464.7) prepared from sample AM1018 in the Hustedt Collection in Bremerhaven (BRM), Germany (SimONSEN 1987, Vol. 1, p. 382).

Type locality: Lake Jurucuí (Lago Jurucuí), Tapajós River, Pará, Brazil. Plankton collected by R. Braun, sample 58, on 13 November 1947.

Ecology and distribution: The only known record of Fragilaria braunii is that of HustedT (1952: 379, figs 41,42 ) from the type locality, Lago Jurucuí (Pará State, Brazil), an oligotrophic Amazonian lake. Additional unpublished records from the HUSTEDT collection include a sample from the Paracuni River (Amazonas State) collected by H. Sioli (slide KA-83; sample AM2314 in BRM collection).

\section{DiscuSSION}

Eunotia enigmatica was commonly found in the phytoplankton community in Southeastern Brazil and seems to be morphologically adapted for an open water existence based on its long, slender and weakly silicified cells. According to Kooistra et al. (2009), pennate diatoms adapt to this planktonic life form by adjusting their morphology to reduce the thickness of its valves, and as a consequence modify the other cell-wall structures (e.g. chamber reduction, larger number of smaller pores). Eunotia enigmatica was also found in abundance in surface sediments, probably due to sedimentation from different habitats (planktonic, benthic) over a long period of time (BENNION 1995). Surface sediment (2 cm) usually accumulates with up to one or two years worth of environmental information (SMOL 2008).

Only a few species of Eunotia can be considered 'truly' planktonic: two of them, E. pseudofragilaria and E. croatana, were described by SIVER et al. (2006) from North Carolina, U.S.A., and have valve outlines similar to those found in Eunotia enigmatica. These, and a few other similar species to E. enigmatica sp. nov., have their morphology summarized in Table 1. Eunotia pseudofragilaria differs by its capitated apices and lower striae density (29-31 in $10 \mu \mathrm{m})$ when compared to E. enigmatica sp. nov., which has mostly subcapitate apices. Eunotia croatana has linear valves, wider sub-capitated apices and narrow rectangular and sigmoid frustules in girdle view. Thus, it differs from E. enigmatica, which has needle-shaped valves and sinuous rectangular frustules in girdle view.

Described in Siver \& Hamilton (2011), Eunotia romanowi SIVER is also similar as well as planktonic but differs from E. enigmatica mainly by its measurements: Eunotia enigmatica has smaller and wider valves with a higher striae density than $E$. romanowi (75-131 $\mu \mathrm{m}$ long, $1.5-2 \mu \mathrm{m}$ wide, $27-29$ striae in 10 $\mu \mathrm{m})$. In addition, the raphe curvature, when observed in SEM, allows the distinction of both species: in $E$. enigmatica the raphe curves slightly up onto the valve face (see pl. 2, Figs 15, 17), whereas in E. romanowi the raphe bends $180^{\circ}$ along the center of the valve face (see pl. 82, fig. 5 in Siver \& Hamilton 2011).

Another species very similar to Eunotia enigmatica sp. nov. is Eunotia weisingii LANGE-BERTALOT, which also has a slender valve outline and sub-capitate apices. Despite these similarities, E. weisingii has wider apices, more linear valves, does not exhibit dorsiventrality, and has lower striae density (24-26 $\mu \mathrm{m}$, LANGE-Bertalot 1993) than E. enigmatica.

The E. asterionelloides species complex, containing some colony forming species with a similar 


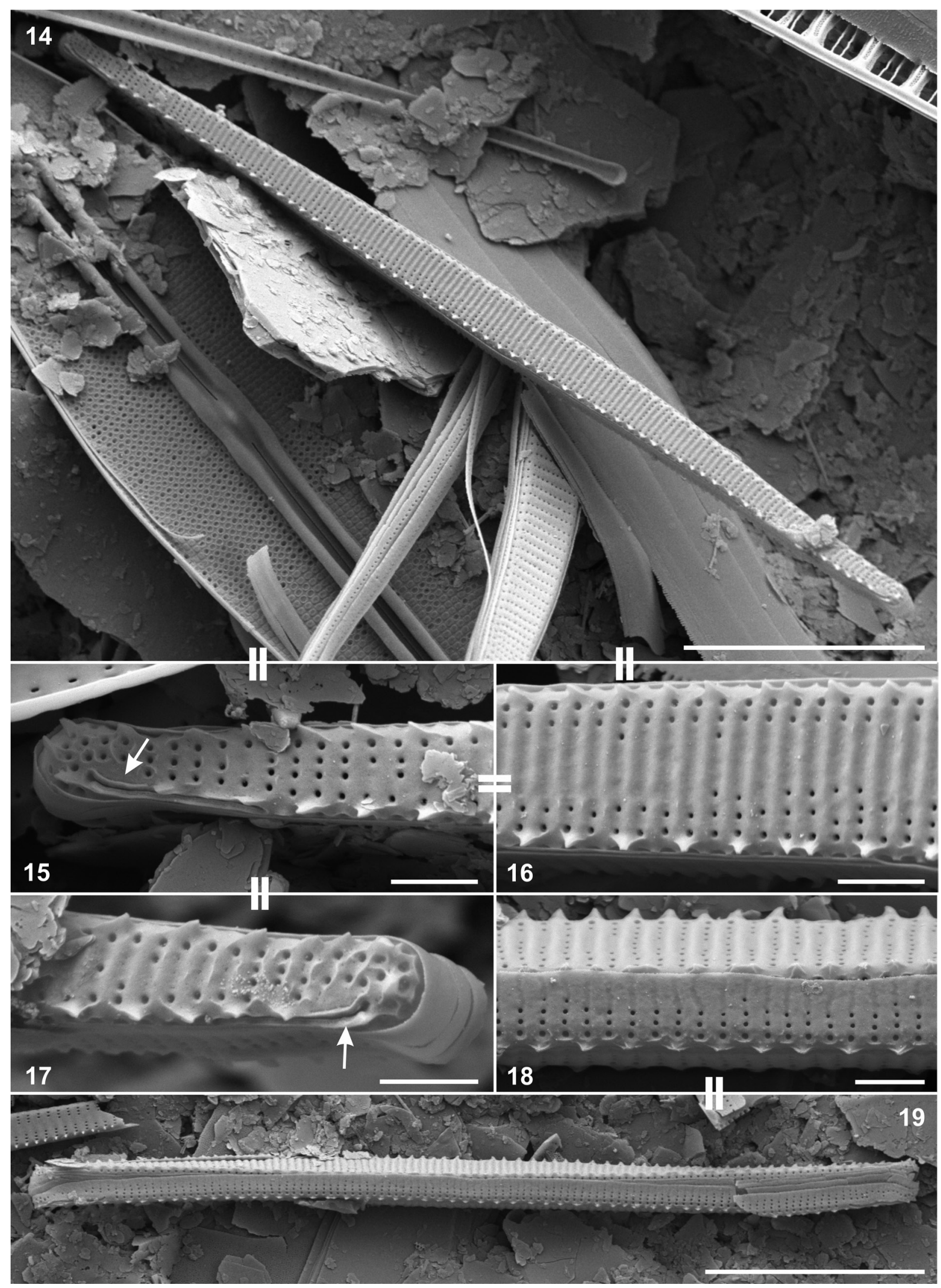

Figs 14-19. Eunotia enigmatica sp. nov. from Pedro Beicht reservoir, SEM images: (14) General external valve view; (15, 17) Apices showing the short lateral raphe (white arrows) in external view of the same specimen as in Fig. 14; (16) Close up of the central area external view showing the uniseriate striation and areolae openings simple and rounded (of the same specimen as in Fig. 14); $(18,19)$ Frustule in girdle view with visible open bands (both images are of the same specimen). Scale bars $10 \mu \mathrm{m}(14,19), 1 \mu \mathrm{m}(15-18)$. Symbol "=" marks images of parts or details of the same specimen. 


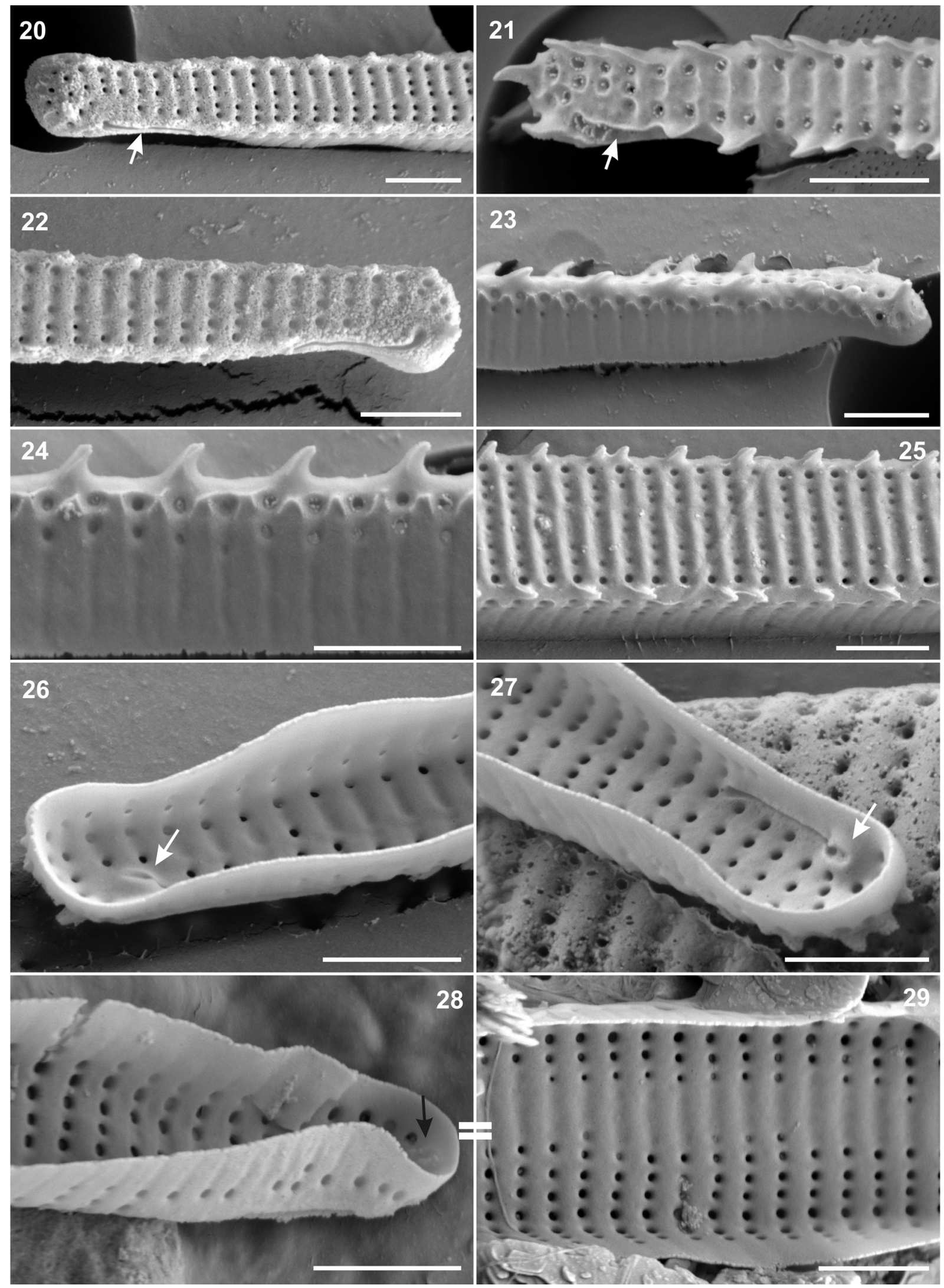

Figs 20-29. Eunotia enigmatica sp. nov. from Pedro Beicht reservoir, SEM images: (20-22) External valve view of apices from different specimens showing the short raphe (white arrows); (23) Apex in girdle view showing one or two rows of pores; (24) Close up of curved spines in girdle view; (25) Close up of central area in external view showing small ridges in between the striae, and areolae occluded by a silica layer in the sternum area; $(26,27)$ Close up of the apices in internal view showing a poorly developed helictoglossa (white arrows); (28) Close up of internal view apex showing rimoportula (black arrow); (29) Close up of internal view central area (of the same specimen as in Fig. 28);. Scale bars $1 \mu \mathrm{m}(20-29)$. Symbol "=" marks images of parts or details of the same specimen. 


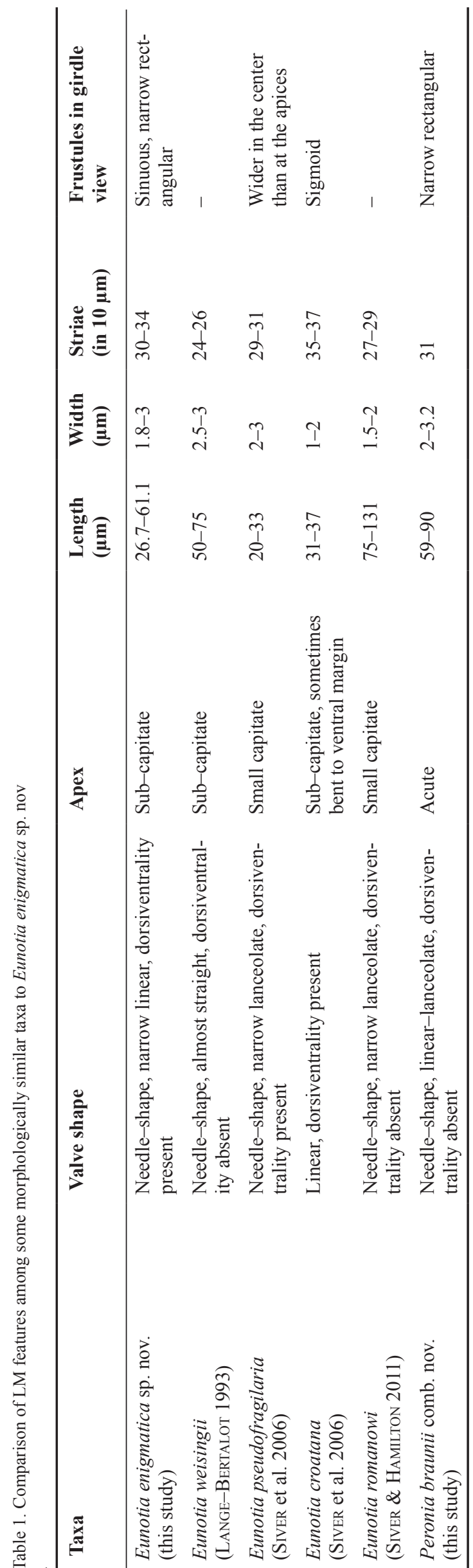

valve outline to E. enigmatica, is also recognized by its planktonic life form (Wetzel et al. 2010). Most of these species, with the exception of Eunotia zasuminensis (CABEJSZEKówNA) KÖRNER, were described from the Brazilian Amazon and differs from E. enigmatica mainly by the linear valve outline and swollen apices. In girdle view, E. gomesii, E. loboi, E. tukanorum and $E$. waimiriorum are larger at the apices and constricted at the center, while in E. enigmatica is sinuous and almost narrowly rectangular. Colonies formed by all the above mentioned species show zigzag and radial patterns, but specimens of E. enigmatica form ribbonlike colonies attached by linking spines (Fig. 13), similar to some species of Fragilaria. Eunotia zasuminensis, originally described from Eastern Europe (Poland) (CABEJSZEKówna 1937), but also rarely occurring in North American reservoirs (Nicholls \& CARNEY 1979), differs from E. enigmatica in having distinct cordiform (= heart shaped) apices.

Similar to species in the E. asterionelloides complex, some species of Asterionella Hassall from Madagascar (BouRRELLY \& MANGUIN 1949) were transferred to Actinella by Kociolek \& RHode (1998) due to the presence of a vestigial raphe and the asymmetry about the apical and transapical axes. These Actinella species, A. candelabrum (Manguin) Kociolek et K. RHode, A. bourrellyi Kociolek et K. RHOde, A. reviersii KocioleK et K. RHODE, can be distinguished from E. enigmatica by the valve outline but mainly by the asymmetry in the transapical axis.

Furthermore, there is potential for confusion between Eunotia enigmatica and some species of Fragilaria. Metzeltin \& Lange-Bertalot (2007, pl. 16, figs 6-9) analyzed material from northern Brazil (HUSTEDT Collection HB 318/45, Lago Jurucuí, detritus) and mistakenly identified a population of E. enigmatica as Fragilaria cf. nanana LANGE-BERTALOT. Although they found only large specimens without the characteristic dorsiventrally shaped valves, the small terminal raphe nodules restricted to the valve poles are visible in their LM images. Besides the absence of slits, Fragilaria tenera var. nanana (LANGE-BeRTALOT) LANGE-BERTALOT et S. Ulrich also differs from E. enigmatica by its lower striae density (18-20 in $10 \mu \mathrm{m}$, LANGE-BERTALOT \& ULRICH 2014).

In the same Hustedt's material (Hustedt Collection HB 318/45, Lago Jurucuí, detritus), Metzeltin \& LANGe-Bertalot (2007, pl. 16, figs 1-5) photographed in light microscopy the long needle-shaped valves of Fragilaria braunii. This taxon has acute apices and conspicuous spines in LM, differing from E. enigmatica which has spines conspicuous only in SEM. Illustrations in scanning electron microscopy of Fragilaria braunii type material are provided here for the first time (Figs 35-56). The type population shows the characteristic spines at each apex mentioned by HusTEDT (1952), but SEM studies revealed two hitherto unknown features: a small raphe and a well-developed 


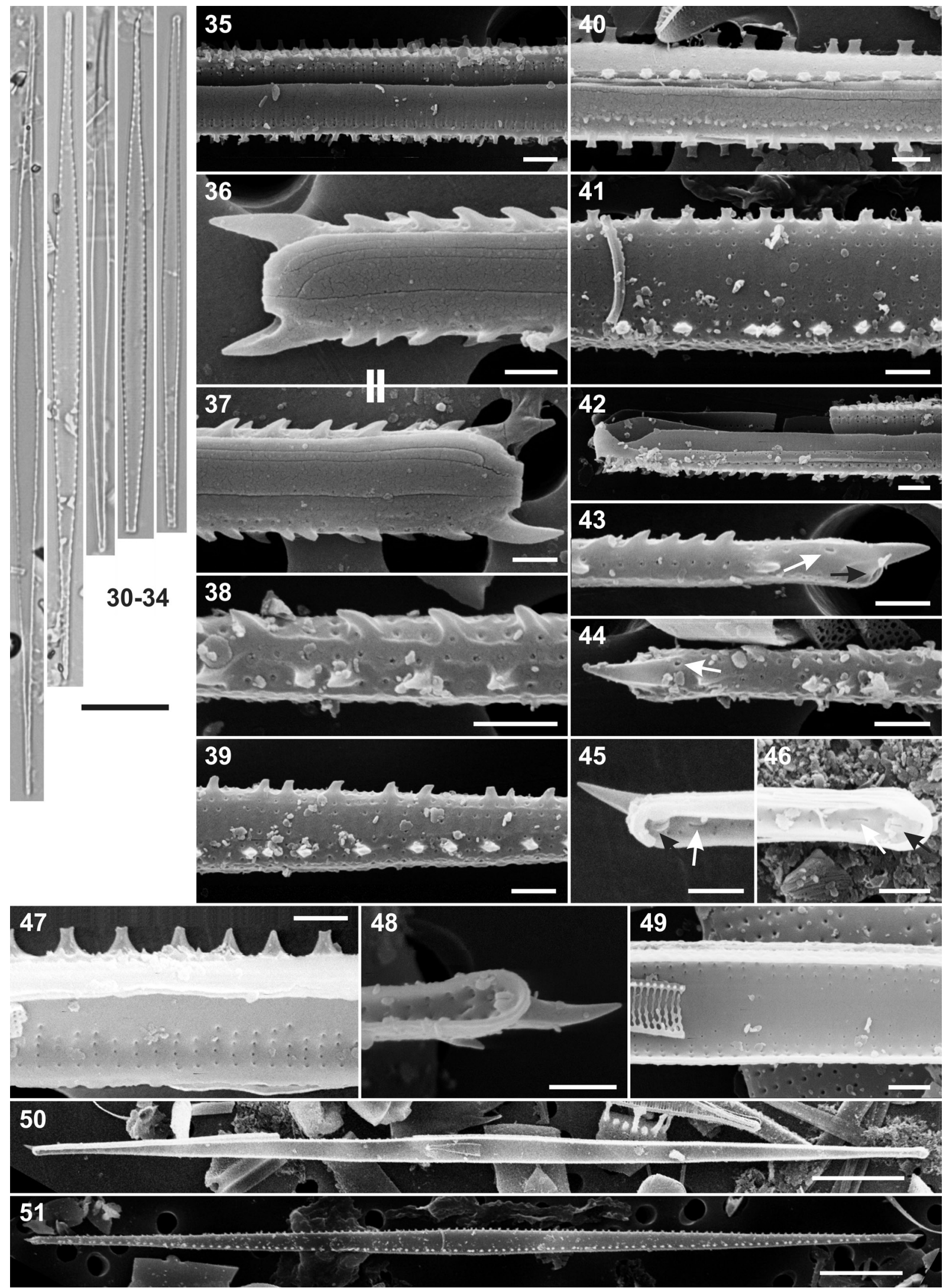

Figs 30-51. Peronia braunii comb. nov. from the type material (AM1018): Figs 30-34. LM images: (30-34) Size diminution series in valve view. Figs 35-51. SEM images: $(35-40,42)$ Close up of frustule in girdle view showing one or two rows of pores and marginal spines; (41) Close up central area in external view showing the simple and rounded areolae; $(43,44)$ Close up of apices in external view showing vestigial raphe (white arrows) and rimoportula pore (black arrow); $(45,46,48)$ Close up of apices in internal view showing the raphe with poorly developed/absent helictoglossa (white arrows), the well-developed rimoportulae (black arrows) and apical spine; $(47,49)$ Detail of central area in internal view; (50) General internal valve view; (51) General external valve view. Scale bars $10 \mu \mathrm{m}(30-34,50,51), 1 \mu \mathrm{m}(35-49)$. Symbol "=" marks images of parts or details of the same specimen. 
rimoportula (Figs 43-46) present at both valve apices.

The existence of the raphe slits precludes assigning Fragilaria braunii to any araphid genus. The small raphe slits positioned on the valve face in the specimens of $F$. braunii suggested that this taxon belongs in the Eunotiales. The raphe slits are straight, oriented in the same direction as the rimoportulae and occur on the valve face near to the median line, features known only for species in Peronia (Round et al. 1990). Actinellopsis, a genus described recently, also has raphe slits placed on the valve face. However, it possesses curved valves as in other Eunotiales (e.g. Amphorotia, Eunotia, Semiorbis) and the raphe is situated close to one margin (TAYLOR et al. 2014). Besides its raphe system, additional features are the characteristic girdle elements and the presence of spines, which both suggest the genus Peronia. Compared with other genera in Eunotiales, spines are shared only by Actinella, some species of Eunotia and Peronia (Round et al. 1990). Frustules in girdle view are narrow, with a few bands overlapping before the poles, similar to that found in Peronia fibula (Williams \& ReID 2008). A 'vestigial' raphe is also known in the genus Bicudoa C.E. Wetzel, LANGE-BERTALOT et ECTOR, recently described from the
Amazon basin. This taxon was placed in Bacillariophyceae but having some similarities to Eunotia; WeTzEL et al. (2012) found some rare specimens with a developed raphe and other specimens with either a vestigial raphe or its absence altogether. Therefore, in spite of the specimens lacking the characteristic heteropolarity, Peronia may be the best choice at this moment based on these SEM images.

Peronia braunii (Hustedt) L.F. CostA, C.E. Wetzel et D.M. WiLliams is longer and symmetrical in apical and transapical axes; however, each apex has a small slit, probably a vestigial raphe. The marginal spines are solid, longer and conspicuous in light microscopy and the frustule in girdle view has few overlapping bands before the poles. Eunotia enigmatica has a long, slender outline, only slightly asymmetrical about the apical axis with significantly reduced raphe slits and a series of siliceous ridges and spines along the valve margin.

The distinctive 'fragilarioid' aspect of Eunotia enigmatica hampers its identification due to its possible co-occurrence with similar Fragilaria species, as observed in São Paulo State reservoirs (PBR and $\mathrm{RCR})$. Additionally, the analysis of the type material of

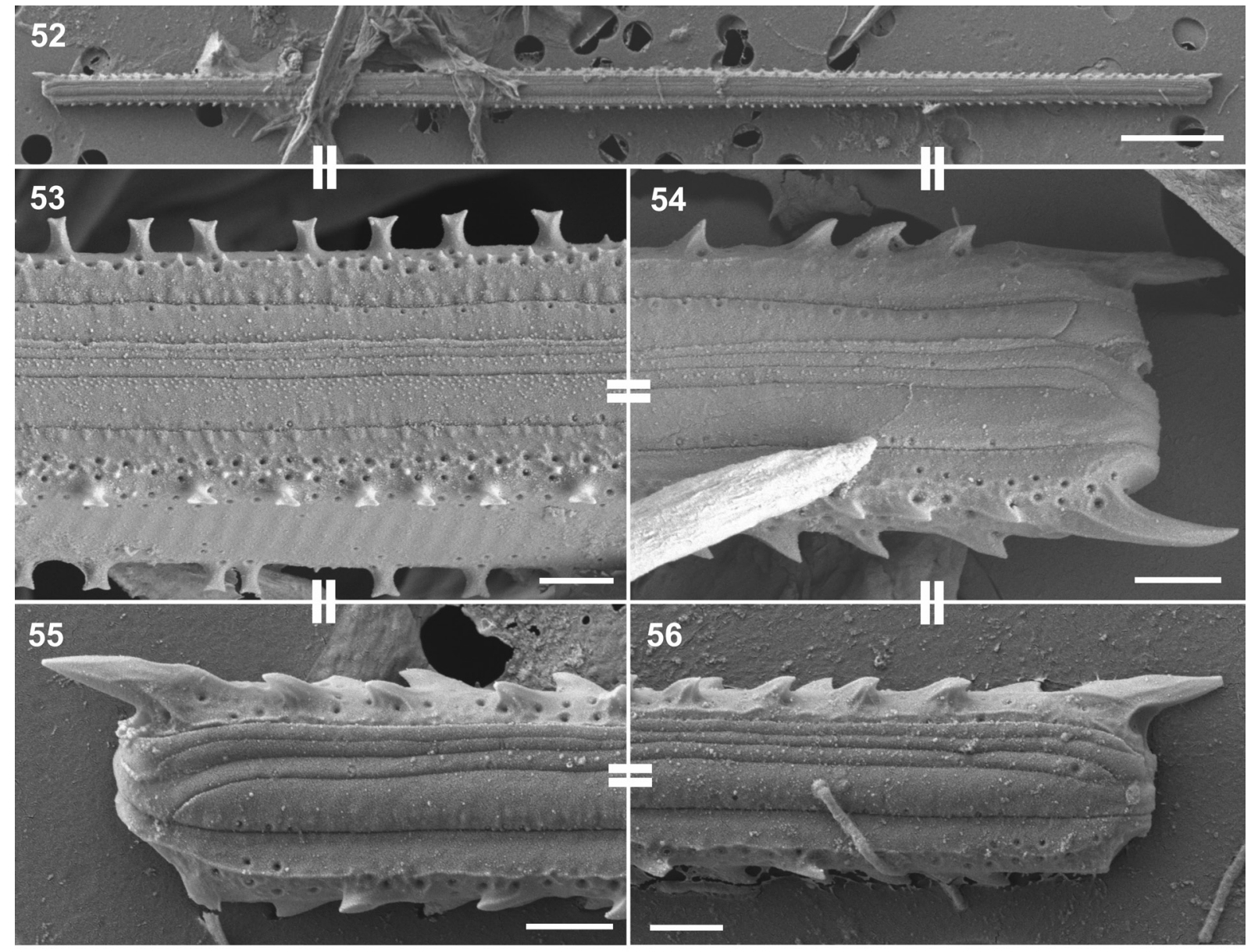

Figs 52-56. Peronia braunii comb. nov. from the type material (AM1018), SEM images of the same specimen: (52) General girdle view; (53) Close up of girdle view showing bifurcate marginal spines; (54-56) Close up of frustule in girdle view showing apices with apical spines and the open bands. Scale bars $10 \mu \mathrm{m}(52), 1 \mu \mathrm{m}(53-56)$. Symbol "=" marks images of parts or details of the same specimen. 
Fragilaria braunii HustedT, a very similarly looking species described from the Brazilian Amazon, allowed its transfer to the genus Peronia based on its short raphe slits on the valve face observed under SEM. Finally, although diatom studies are increasing in Brazil (e.g. Wetzel et al. 2011; Tremarin et al. 2012, 2014, 2016; Cavalcante et al. 2013; Wengrat et al. 2015; Almeida et al. 2016; Bertolli et al. 2016; Da Silva et al. 2016; FAUSTINO et al. 2016; MARQUARDT et al. 2016), more effort is needed to better understand the distribution and ecology of Eunotia enigmatica and similar Fragilaria species, thus enhancing the knowledge of tropical/subtropical diatom species and their use in water quality assessment.

\section{ACKnowledgements}

This work was carried out within the framework of the AcquaSed project supported by funds from FAPESP (Fundação de Amparo à Pesquisa do Estado de São Paulo, AcquaSed Project n 2009/538989), and was undertaken as part of LFC's M.Sc. thesis at the Instituto de Botânica - IBt (São Paulo, Brazil) (masters fellowship process ${ }^{\circ}$ 2014/15109-0 and BEPE process $n^{\circ} 2014 / 25311-1$ to LFC). Funding was also provided by $\mathrm{CNPq}$, Conselho Nacional de Desenvolvimento Científico e Tecnológico (Grant 310940/2013-3 to DCB) and LIST, Luxembourg Institute of Science and Technology (DIATOMS project). We are also grateful for the logistic support during fieldwork provided by the personnel from SABESP (Divisão de Recursos Hídricos Metropolitanos Sudoeste).

\section{REFERENCES}

Almeida, P.D. \& Bicudo, D.C. (2014): Diatomáceas planctônicas e de sedimento superficial em represas de abastecimento da Região Metropolitana de São Paulo, SP, Sudeste do Brasil. - Hoehnea 41: 182-207.

Almeida, P.D.; Morales, E.A.; Wetzel, C.E.; Ector, L. \& BicuDo, D.C. (2016): Two new diatoms in the genus Fragilaria Lyngbye (Bacillariophyceae) from tropical reservoirs in Brazil and comparison with type material of $F$. tenera. - Phytotaxa 246: 163-183.

BenNion, H. (1995): Surface-sediment diatom assemblages in shallow, artificial, enriched ponds and implications for reconstructing trophic status. - Diatom Research 10: $1-19$.

Bertolli, L.M.; Talgatti, D.M. \& Torgan, L.C. (2016): Nitzschia papillosa (Bacillariaceae, Bacillariophyta): a new species from a Brazilian salt marsh. - Phytotaxa 247: 75-84.

Bicudo, D.C.; Tremarin, P.I.; Almeida, P.D.; Almeida-ZorZal, S.; Wengrat, S.; Faustino, S.B.; Costa, L.F.; BartozeK, E.C.R.; Rocha, A.C.R.; Bicudo, C.E.M. \& Morales, E.A. (2016): Taxonomy and ecology of Aulacoseira species (Bacillariophyta) from tropical reservoirs in Brazil. - Diatom Research 31: 199-215.

Bourrelly, P. \& Manguin, E. (1949): Contribution à l'étude de la flore algale d'eau douce de Madagascar: Le Lac de Tsimbazaza. - Mémoires de l'Institut Scientifique de Madagascar, Série B, 2: 161-190, 7 pls.

Burliga, A.L.; Kociolek, J.P.; Salomoni, S.E. \& Figueiredo, D. (2013): A new genus and species in the diatom family Eunotiaceae Kützing (Bacillariophyceae) from the Amazonian hydrographic region, Brazil. - Phytotaxa 79: 47-57.

Cabejszekówna, I. (1937): Fragilaria zasuminensis n. sp. W
Jeziorze Zasuminskim na Polesiu [Fragilaria zasuminensis n. sp. dans le lac Zasumińskie en Polésie]. Archivum Hydrobiologii i Rybacktwa (Archives d'Hydrobiologie et d'Ichthyologie), Suwalki 10: 423-425.

Cavalcante, K.P.; Tremarin, P.I. \& Ludwig, T.A.V. (2013): Taxonomic studies of centric diatoms (Diatomeae): unusual nanoplanktonic forms and new records for Brazil. - Acta Botanica Brasilica 27: 237-251.

CEPAGRI - Centro de Pesquisas Meteorológicas e Climáticas Aplicadas a Agricultura (2015): A classificação climática de Koeppen para o Estado de São Paulo. - Available online at http://www.cpa.unicamp.br/outras-informacoes/clima-dos-municipios-paulistas.html; searched on September 24, 2015.

Cox, E.J. \& Ross, R. (1981): The striae of pennate diatoms. - In: Ross, R. (ed.): Proceedings of the Sixth Symposium on Fossil and Recent Diatoms. - pp. 267-278. O. Koeltz, Koenigstein.

Cunha, D.G.F.; Calijuri, M.C. \& Lamparelli, M.C. (2013). A trophic state index for tropical/subtropical reservoirs (TSItsr). - Ecological Engineering 60: 126-134.

Da Silva, W.J.; Ruwer, D.; Nogueira, I. \& Dunck, B. (2016): The genus Pinnularia (Bacillariophyta, Pinnulariaceae) from Lago dos Tigres, Britânia, Goiás, Brazil. - Biota Neotropica 16: e20150028. http:// dx.doi. org/10.1590/1676-0611-BN-2015-0028.

European Committee For Standardization (2014): European Standard. EN 13946. Water quality - Guidance for the routine sampling and preparation of benthic diatoms from rivers and lakes. -14 pp., CEN, Brussels.

Faustino, S.B.; Fontana, L.; Bartozek, E.C.R.; Bicudo, C.E.M. \& Bicudo, D.C. (2016): Composição e distribuição das diatomáceas de perfil sedimentar e sedimentos superficiais em reservatório de abastecimento no Sudeste do Brasil. - Biota Neotropica 16: e20150129. http://dx.doi. org/10.1590/1676-0611-BN-2015-0129.

Fontana, L.; Albuquerque, A.L.S.; Brenner, M.; Bonotto, D.M.; Sabaris, T.P.P.; Pires, M.A.F.; Cotrim, M.E.B. \& Bicudo, D.C. (2014): The eutrophication history of a tropical water supply reservoir in Brazil. - Journal of Paleolimnology 51: 29-43.

Furey, P.C.; Lowe, R.L. \& Johansen, J.R. (2011): Eunotia Ehrenberg (Bacillariophyta) of the Great Smoky Mountains National Park, USA. - Bibliotheca Diatomologica 56: $1-133$.

Hustedt, F. (1952): Neue und wenig bekannte Diatomeen. IV. Botaniska Notiser 4: 366-410.

KocioleK, J.P. (2000): Valve ultrastructure of some Eunotiaceae (Bacillariophyceae), with comments on the evolution of the raphe system. - Proceedings of the California Academy of Sciences 52: 11-21.

Kociolek, J.P. \& Rhode, K. (1998): Raphe vestiges in “Asterionella" species from Madagascar: evidence for a polyphyletic origin of the araphid diatoms? - Cryptogamie, Algologie 19: 57-74.

Kociolek, J.P.; Theriot, E.C.; Williams, D.M.; Julius, M.; StoERMER, E.F. \& KingSTON, J.C. (2015): Centric and araphid diatoms. - In: Wehr, J.D.; Sheath, R.G. \& KocioleK, J.P. (eds): Freshwater Algae of North America. Ecology and Classification. - pp. 653-772, Academic Press, San Diego.

Kooistra, W.H.C.F.; Forlani, G. \& De Stefano, M. (2009): Adaptations of araphid pennate diatoms to a planktonic existence. - Marine Ecology 30: 1-15.

Kulikovskiy, M.; Lange-Bertalot, H.; Witkowski, A.; KhurSevich, G.K. \& Kociolek, J.P. (2015): New species of Eunotia (Bacillariophyta) from Lake Baikal with comments on morphology and biogeography of the genus. - Phycologia 54: 248-260. 
Lange-Bertalot, H. (1993): 85 Neue Taxa und über 100 weitere neu definierte Taxa ergänzend zur Süßwasserflora von Mitteleuropa, Vol. 2/1-4. - Bibliotheca Diatomologica 27: $1-454$.

Lange-Bertalot, H. \& Ulrich, S. (2014): Contributions to the taxonomy of needle-shaped Fragilaria and Ulnaria species. - Lauterbornia 78: 1-73.

Lange-Bertalot, H.; Bą, M. \& Witkowski, A. (2011): Eunotia and some related genera. - In: LANGE-BERTALOT, H. (ed.): Diatoms of Europe. - 747 pp., A.R.G. Gantner Verlag K.G., Ruggell, distributed by Koeltz Scientific Books, Koenigstein.

Marquardt, G.C.; Da Rocha, A.C.R.; Wetzel, C.E.; Ector, L. \& Bicudo, C.E.M. (2016): Encyonema aquasedis sp. nov. and Kurtkrammeria salesopolensis sp. nov.: two new freshwater diatom species (Cymbellales, Bacillariophyceae) from an oligotrophic reservoir in southeastern Brazil. - Phytotaxa 247: 62-74.

Metzeltin, D. \& Lange-Bertalot, H. (2007): Tropical diatoms of South America II. Special remarks on biogeography disjunction. - In: Lange-Bertalot, H. (ed.), Iconographia Diatomologica. Annotated Diatom Micrographs. Diversity-Taxonomy-Biogeography, Vol. 18. - 877 pp., A.R.G. Gantner Verlag K.G., Ruggell.

Nicholls, K.H. \& CARNEY, E.C. (1979): The rare planktonic diatom Eunotia zasuminensis in Canada. - Canadian Journal of Botany 57: 1150-1154.

Novitski, L. \& Kociolek, P. (2005): Preliminary light and scanning electron microscope observations of marine fossil Eunotia species with comments on the evolution of the genus Eunotia. - Diatom Research 1: 137-143.

Patrick, R.M. \& ReImer, C.W. (1966): The diatoms of the United States. Exclusive of Alaska and Hawaii. Vol. 1. Fragilariaceae, Eunotiaceae, Achnanthaceae, Naviculaceae. - Monographs of the Academy of Natural Sciences of Philadelphia 13: 1-688.

Pavlov, A. \& Levkov, Z. (2013): Diversity and distribution of taxa in the genus Eunotia Ehrenberg (Bacillariophyta) in Macedonia. - Phytotaxa 86: 1-117.

Potapova, M.G.; Hamilton, P.B.; Kopyrina, L.I. \& Sosina, N.K. (2014): New and rare diatom (Bacillariophyta) species from a mountain lake in Eastern Siberia. - Phytotaxa 156: 100-116.

Round, F.E.; Crawford, R.M. \& Mann, D.G. (1990): The Diatoms. Biology \& morphology of the genera. - 747 pp., Cambridge University Press, Cambridge.

Simonsen, R. (1979): The diatom system: ideas on phylogeny. Bacillaria 2: 9-71.

Simonsen, R. (1987): Atlas and catalogue of the diatom types of Friedrich Hustedt, Vol. 1-3. - 525 pp., pls 1-395, pls 396-772., J. Cramer, Gebrüder Borntraeger, Berlin \& Stuttgart.

Siver, P.A. \& Hamilton, P.B. (2011): Diatoms of North America. The freshwater flora of waterbodies on the Atlantic Coastal Plain. - In: LANGe-Bertalot, H. (ed.): Iconographia Diatomologica. Annotated Diatom Micrographs. Diversity-Taxonomy-Biogeography, Vol. 22. - 916 pp., A.R.G. Gantner Verlag K.G., Ruggell.

Siver, P.A.; Hamilton, P.B. \& Morales, E.A. (2006): Two new planktic species of Eunotia (Bacillariophyceae) from freshwater waterbodies in North Carolina, U.S.A. - Algological Studies 119: 1-16.

SmoL, J.P. (2008): Pollution of Lakes and Rivers - a paleoenvironmental perspective, $2^{\text {nd }}$ ed. -383 pp., Blackwell Publishing, Oxford.

Spaulding, S. (2015): Peronia. In Diatoms of the United States. Retrieved April 30, 2016, from http://westerndiatoms. colorado.edu/taxa/genus/peronia

Taylor, J.C.; Karthick, B.; Kociolek, J.P.; Wetzel, C.E. \& Co-
CQUYT, C. (2014): Actinellopsis murphy gen. et spec. nov: A new small celled freshwater diatom (Bacillariophyta, Eunotiales) from Zambia. - Phytotaxa 178: $128-137$.

Theriot, E.C.; Ashworth, M.; Ruck, E.; Nakov, T. \& Jansen, R.K. (2010). A preliminary multigene phylogeny of the diatoms (Bacillariophyta): challenges for future research. - Plant Ecology and Evolution 143: 278-296.

Tremarin, P.I.; Ludwig, T.A.V. \& Torgan, L.C. (2012): Ultrastructure of Aulacoseira brasiliensis sp. nov. (Coscinodiscophyceae) and comparison with related species. Fottea 12: 171-188.

Tremarin, P.I.; Ludwig, T.A.V. \& Torgan, L.C. (2014): Four new Aulacoseira species (Coscinodiscophyceae) from Matogrossense Pantanal, Brazil. - Diatom Research 29: 183-199.

Tremarin, P.I.; Kim, K.I.M.B.; Marra, R.C. \& Ludwig, T.A.V. (2016): Additional data on morphology of Actinella leontopithecus-rosalia Costa (Bacillariophyta, Eunotiaceae). - Phytotaxa 247: 259-266.

Van de ViJver, B.; de HaAn, M. \& Lange-Bertalot, H. (2014): Revision of the genus Eunotia (Bacillariophyta) in the Antarctic Region. - Plant Ecology and Evolution 147: 256-284.

Wengrat, S.; Marquardt, G.C.; Bicudo, D.C.; Bicudo, C.E.M.; Wetzel, C.E. \& Ector, L. (2015): Type analysis of Cymbella schubartii and two new Encyonopsis species (Bacillariophyceae) from southeastern Brazil. - Phytotaxa 221: 247-264.

Wetzel, C.E.; Ector, L.; Hoffmann, L. \& Bicudo, D.C. (2010): Colonial planktonic Eunotia (Bacillariophyceae) from Brazilian Amazon: Taxonomy and biogeographical considerations on the E. asterionelloides species complex. - Nova Hedwigia 91: 49-86.

Wetzel, C.E.; Ector, L.; Hoffmann, L.; Lange-Bertalot, H. \& Bicudo, D.C. (2011): Two new periphytic Eunotia species from the neotropical Amazonian 'black waters', with a type analysis of E. braunii. - Diatom Research 26: $135-146$.

Wetzel, C.E.; Lange-Bertalot, H.; Morales, E.A.; Bicudo, D.C.; Hoffmann, L. \& Ector, L. (2012). Bicudoa amazonica gen. nov. et sp. nov. (Bacillariophyta) - a new freshwater diatom from the Amazon basin with a complete raphe loss in the Eunotioid lineage. - Phytotaxa 75: $1-18$.

Williams, D.M. \& ReID, G. (2006): Amphorotia nov. gen., a new genus in the family Eunotiaceae (Bacillariophyceae), based on Eunotia clevei Grunow in Cleve et Grunow. Diatom Monographs 6: 1-153.

Williams, D.M. \& Reid, G. (2008): Type material of Peronia fibula: morphology, systematics and relationships. - In: Likhoshway, Y. (ed.): Proceedings of the Nineteenth International Diatom Symposium. Listvyanka, Irkutsk, Russia, $28^{\text {th }}$ August $-3^{\text {rd }}$ September 2006. - pp. 141150, Biopress Limited, Bristol.

(C) Czech Phycological Society (2017)

Received May 30, 2016

Accepted October 10, 2016 